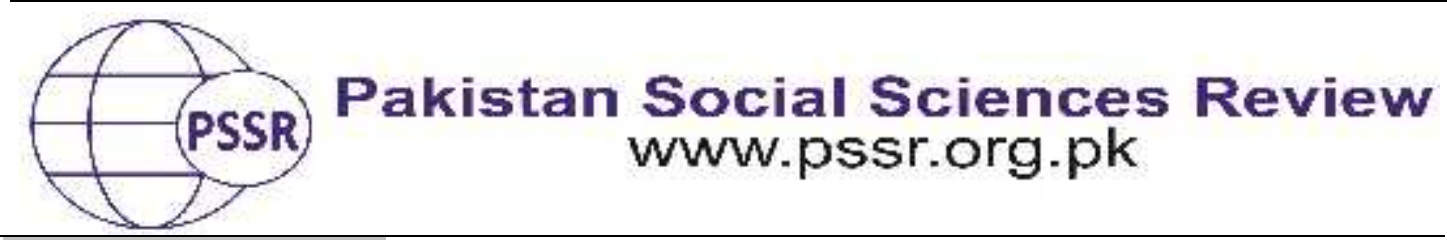

RESEARCH PAPER

\title{
CPEC and Logistics Development in Pakistan: Legal Impediments and the Way Forward
}

\author{
Rao Qasim Idrees ${ }^{1}$ Jawwad Riaz ${ }^{2}$ Zaheer Iqbal Cheema ${ }^{3}$
}

1. School of Law, University of Gujrat, Punjab, Pakistan

2. Assistant Professor, University Law College, University of Punjab, Lahore, Punjab, Pakistan

3. Assistant Professor, University Law College, University of Punjab, Lahore, Punjab, Pakistan

\begin{tabular}{|c|c|}
\hline PA] & \\
\hline 5,2020 & $\begin{array}{l}\text { This research article primarily ex } \\
\text { infrastructure and schemes by the } \\
\text { and further discusses the Pak } \\
\text { initiatives to prepare their polic } \\
\text { with the needs arising from fut }\end{array}$ \\
\hline $\begin{array}{l}\text { Keyr } \\
\text { Chin } \\
\text { Econ } \\
\text { Corr } \\
\text { Fore } \\
\text { Inve } \\
\text { Logi }\end{array}$ & $\begin{array}{l}\text { plan } \\
\text { transp } \\
\text { foreig } \\
\text { arrang } \\
\text { Pakist }\end{array}$ \\
\hline $\begin{array}{l}\mathrm{Co} \\
\mathrm{Au}\end{array}$ & $\begin{array}{l}\text { ernational standard of regional connectivity through } \\
\text { onomic corridors is discussed according to the current } \\
\text { ateral agreements and applicable laws. The concluding } \\
\text { tion of this study enunciates that Chinese investment and } \\
\text { mestic efficient management of overland logistics would help } \\
\text { kistan reap maximum benefits of the China-Pakistan } \\
\text { onomic Corridor (CPEC). Stakeholders belonging to the } \\
\text { erland logistics sectors have stressed the need for improved } \\
\text { nsport infrastructure and updated logistics and freight } \\
\text { warders laws for efficient economic development through } \\
\text { EC }\end{array}$ \\
\hline
\end{tabular}

\section{Introduction}

Alam, (2014) states that Pakistan and China have strong bilateral investment treaty agreements; however such agreements cannot provide the suitable environment for CPEC logistics investment and required to be amended. Pakistan 
government has a long term alliance with its Chinese counterparts and these states successfully developed historical economic relationships. Furthermore, China and Pakistan successfully develop active and comprehensive foreign direct investment framework but the recent Belt and Road Initiative (BRI) plan with its offshoot ChinaPakistan Economic Corridor (CPEC) significantly enhances the volume of products from China into Pakistan. BRI plan further elaborates that China intends to sponsor local firms to create broad nationwide logistics and connectivity arrangement for encouragement of trade and industrial development within economical context. The BRI framework provides China further connections by way of developing economical terms with the world in addition to growth plans. Therefore CPEC surely provide various prospects for China and Pakistan. Idrees et al, (2018) argue that Chinese projects analysis for doing logistics business in Pakistan along with prevailing long term trade environment advocate the fact that such bilateral investment confirms shift in the direction of more reliable economic developments. However, different legal and policy aspects of the Chinese schemes expose high threats to disturb the overall plan. Furthermore, to put together the ideas with proposed plan and improving the legality of its functioning policies, further advances requirement of practical way outs regarding cross border problems and over land logistics mechanism under mega foreign investment regimes.

\section{Logistics Investment}

McGinnis, (1994) informs that the word logistics came into practice in 1960s and at present it is comprehensively utilized. In any case, up to this point it has been struggling up for a thorough definition. Logistics is considered as different activities arrangement in which products are transported from manufacturing place to another place for customer's utility. For general definition it very well may be said that logistics process includes different activities such as, warehousing, products preserving, packaging, material safety which are different objects within definition of logistics. Logistics further provides the transportation and movement of goods within different points and make sure the timely and safe handling towards destinations (Council of Supply Chain Management Professionals). Besides, logistics enhances the capabilities of production arrangements while supplying raw material and other necessary elements. Logistics also presumes as fundamental action as well as builds the effectiveness of all other capacity of production network. With respect to effectiveness of logistics, it depends upon the infrastructure and administration game plan. There is important link between efficient logistics management and wellbuilt infrastructure. The reason is that a well-built infrastructure like roads, bridges, motorways, warehouses, airports as well as sea ports offer fast and cost effective logistics chain to improve the economy of the country.

Bowersox, (2000) states that it is appropriate to say that logistics administration can be improved drawing upon better supply chain system and effective organization of transport suppliers and customers. As examined by Shan, "logistics effectiveness depends upon the infrastructure". For getting better results from logistics sector, the physical infrastructure improvement is inevitable. 
Sreenivas, (2011) emphasises that in current scenario, logistics assumes central part for the success and promotion of the business in any company or organisation. Effective endeavors make models for clients as well as for companies with new logistics capacities. Along these lines this concept becomes a useful apparatus within organizations. However, for numerous organizations, this concept is underrated and they are more focused on cost ignoring the position of logistics being vital asset. Nonetheless, the importance of logistics cannot be under rated because it is a beneficial asset as well as organisations optimized their profits by effective use of it. Logistics certainly assumes basic part in each nation's economic improvement. In this context, logistics arrangements agreements, if they are to be made by any means between China and Pakistan, will face a number of problems. For example, China has its own goals and standards for the development of CPEC, while Pakistan is lacking comparable goals and standards to pursue its own vital interests. Pakistan's overall national plans as to road connectivity, railway network, cross border trade, citizen's economic well-being, etc., are inevitable to changes as CPEC move forwards adopting international laws and treaties norms and best practices. Since China has more extensive and broad objectives in CPEC activity, and China is more likely to get maximum benefits and extend its relations through better policies, Pakistan must be permitted to acquire healthy advantages and not to be confined just to corridor of connectivity. Administrative, legal as well as strategically important concerns in the direction of accomplishing sustainability in economic and social progress can be considered as the main issues for the state. Shapiee, (2017) informs that China has already demanded amendments to various related Pakistani domestic laws to meet the requirements under CPEC as condition for continuance of logistics investment. In this regard, examples are the "Special Economic Zones Act, 2012, Competition Act, 2010 and Public Procurement Regulatory Rules, 2004". Consequently, the weak and obsolete legal system further produces complications and unproductive environment for local and international laws. However, some important legal and public policy aspects need to be addressed by Pakistan. In this regard, current research discusses CPEC logistics investment and impacts to Pakistan. This will be followed by an analysis of model of CPEC logistics investment commitments and the very legal character of freight forwarders investment by both countries, including the current legal system related to logistics investment vis-a-vis CPEC and the problems arising from current logistics investment model. While discussing about logistics, the importance of transport management is necessary to look into. Mentzer, (2011) states that with the process of public sector involvement and concept of globalization which has taken place since 1950, logistics becomes more prominent and focused. The best example here is manufacturing and delivery sectors where logistics play key role to attain maximum results. Current research area principally discusses the importance as well as situation of expense regarding price of movement of goods and required time to deliver such goods. Furthermore, the ultimate goal of logistics is to make sure the ready to use products further delivered to concerned person. Logistics involves receiving requests from customers, storing products at safe place, and moving them from one place to another. In the light of above definitions, transportation is a noteworthy piece of logistics. Thusly the 
decision of transportation mode for the development of products is vital. To increase greatest benefit, associations try to think about various parts of transportation for mode determination. Transportation is a large activity which comprised of different segments. However, there are two basic elements which play basic role in determination of profit. These are the expenses and time required to reach at destination point. Current research aims to highlight the significance of logistics and prevailing situation in Pakistan. This further extends to analyse ancillary governing and management laws to find better ways for CPEC logistics investment in Pakistan.

\section{Role of Transport and Logistics Investment in Regional and Transnational Economic Corridor}

This part of the research discusses generally the importance of transport and logistics investment for building regional economic corridor and particularly its significance for CPEC. It is widely thought today that improved connectivity through bilateral and regional integration together with spending money on transportation networking is by way of putting finance for trade and infrastructure projects with the assistance of facilitated trade policy. In this strategy, the respective and regional congruity can include common participation in the economy. In connection to these efforts, better logistics and transport infrastructure may improve the foreign investment opportunities and lower down the expenses and make the country to perform better. Improved logistics can also improve the functions of special economic zones (SEZs) and their productivity. In such manner, current research portrays well-constructed connection between enhanced highways and road communications, poverty decrease along with expanded production. (Fan, 2017) analyses Chinese physical infrastructure set-up and reveals that one and half percent increase for road density enhanced country's GDP in both farming and nonfarming sectors and also labor sectors up to $0.09,0.11$ and 0.17 percentages respectively (Asian Development Bank, 2002). Increment efficiency prompts expanded development and in the long run lessens the poverty which is one of the key target of Chinese SREB and its branch CPEC plan. Glewwe, (1990) states that development flexibility can be seen of poverty frequency up to 0.34 along with 0.10 meant for Indonesian regions while creating physical highway networks in addition to immature highways physical infrastructure. Such data demonstrates destitution turn around 0.33 and 0.09 rates respectively in a specific order, for each one rate point development in commonplace GDP (Asian, Development Bank, 2010). In another investigation, Glewwe depicts and suggests about smooth roads presence a reason for diminishing impoverishment around $67.5 \%$ with regard to lower income people living in Vietnam (Klaus, 2014). These examinations demonstrate the basic role of transport and logistics infrastructure in business, poverty eradication, expanded efficiency and so forth. There is some work existing that gives evaluations to demand of better roads and connectivity network within South Asian region. It is further provided that the assessed interest regarding road and rail network investment for around 30 Asian states in light of their development plans and combined supply of physical infrastructure within these particular states can rise up to $93.5 \%$ in 2020, along with most extreme increment for networking physical 
infrastructure as well. In a similar vein, the aggregate reduce regarding business expense around 2020 inferable from infrastructure projects between 2011 to 2020 time period is $15 \%$ and $\$ 12.8$ for aggregate business an incentive for both countries, separately (Zhai, 2018). CPEC is among endeavors with regard to bigger connectivity arrangements between two countries while establishing infrastructure through road, rail links, oil and gas transmission lines along with social connections to offer better investment environment. In addition proposed CPEC plan arranges to convert economies more money related accomplishments and advancement. The ebb and flow of research proposals additionally creates certain goals towards locating presumable results in connection to China Pakistan Economic Corridor. It builds up importance of CPEC projects towards investigation about present business and roads and railways schemes help condition. Besides this research permits examination and impact on trade, income, and welfare accomplishments of local markets for recognising economic participation between concerned nations within range of connectivity networks.

In this regard global competiveness report issued in 2013, offers particulars in relation to circumstance provided under by and large networks, railway links, roads infrastructure, air transportation systems towards around 140 nations. As per results, unfortunately Pakistan exists behind the other states in the region which includes Singapore, Malaysia, India and other South Asian and South East Asian nations for quality of railway tracks, sea ports. However, roads and transport sector is an exemption in which Pakistan exists at better position against regional economic nations. In case of China, it introduces its all-around improved infrastructure of roads, railways and aeronautics in correlation with other regional trade partners.

In addition, the comparison among Pakistan and other states in the region regarding physical infrastructure and networking, the country provides with wellbuilt highways and roads against SAARC and ECO member nations. However, Pakistan is still far behind in the construction of road and other physical infrastructure by ASEAN, NAFTA as well as EU member nations.

Pakistan additionally in sectors of sea port infrastructure and sea worthiness falls not very high with in ECO as well as SAARC member nations. In such progress, Pakistan is still far behind the ASEAN, NAFTA and EU member countries. Subsequently advancement and investment both regarding quality from innovative change and commitment and money related assets are required to be accomplished for getting foreseen infrastructure advancement and improvement towards help up the economy by increasing GDP of Pakistan by and large around $7.5 \%$ to $8.5 \%$ development. 


\section{Model of Overland Logistics Investment in CPEC}

This research goes further while paying regard for China Pakistan Economic Corridor transport and logistics projects as well as regional trade management system. Essentially this economic corridor observes another section in the advancement of the affiliation through improving trade and industry participation in addition to connectivity specifically within focal point amongst both countries. Among many others, cooperation and assistance in progress and growth of economic situation in Pakistan and on prescribed routes of CPEC is the fundamental objective of CPEC (China Pakistan economic corridor council, JCC OF CPEC $3^{\text {rd }}$ meeting, 2017).

Both countries have decided to fully implement the plans which they have initiated on grounds of mutual assistance and enhanced understanding. Through these projects not only Pakistan can better realize its economic problems but China also further develops its western parts at the border with Pakistan. Moreover, the vision of Chinese President further promotes the need of harmonization and unification between different countries and their legal systems with help of BRI policy. This policy further promote the better connections between different nations, up gradation of logistics infrastructures throughout regions, better broadcasting communications, energy generation plants and business ties between individuals of the region. The proposed plan and projects with CPEC strategy clearly envisage Chinese BRI policy as Pakistan ports situated at Gwadar and Karachi offers main entry points into Arabian Sea.

There are significant institutional efforts from both China and Pakistan to make CPEC successful as much as possible. For such reasons, NDRC "National Development and Reform Commission" further creates different working committees on national level. On the other hand, Pakistan has also established different committees for these projects. On China side, NDRC establishes JCC "Joint Cooperation Committee" to look after the projects composition and progress. JCC covers physical infrastructure, electricity generation and construction projects. Furthermore, 33 schemes and progress work including electricity development, logistics and transport development and Gwadar port construction consider early harvest Programs and finalise to be completed on priority basis (Ministry of Ports and Shipping, Gwadar port authority, 2015).The total value of these schemes is around $\$ 43$ billion. A plan of the long haul arranging has been affirmed relating to the premise of arranging from China and Pakistan side, improvement objectives, perceived key zones and significant activities which include spatial service areas and industrial zones, improvement of an intermodal transportation framework, use of advance information technology services, electricity collaboration, businesses establishment schemes, agribusiness advancement, participation for wellspring of income undertakings and individuals to individuals associations and money related common guide. 


\section{Gwadar Infrastructure Planning}

For the success of CPEC plans, Gwadar port is considered as central position and it offers gateway to CPEC projects. During the second meeting of Joint Cooperation Committee (JCC) in 2014, 11 projects were categorized as early harvest programs and five more Gwadar related projects were also categorized as early harvest programs during the second JCC meeting in 2015 and 3 to 5 years time period considered as completion time of such projects (Ministry of Foreign Affairs, Government of Pakistan, 2015).

\section{Gwadar Port Expressway}

Gwadar Port Expressway is main highway which is under development at Gwadar port. It is six lane highways which is planned to be complete in 2020. This expressway will further connect Gwadar with Makran Highway.

- Category: multi track (6) (edge) way road during first phase added two way railway line

- Total span: 18.8 kilometres

- Off Shore length: 4.4 kilometres

- On Shore length: 14.5kilometres

- Number of bridges: 1

- Number of pedestrian ways: 2

- Estimated cost measured by concerned committee (ECNEC) is 14,070 Million (Rs)

- Cost for FEC: 13,543 Million (Rs)

- There is no interest charge by the Chinese government for providing this amount of loan

\section{Free Economic Zone Area}

Free Economic Zone area is established near the important highways like Makran coastal road and also linked to Gwadar port terminals for better efficiency of economic zone. Such region impetuses are developed under international standards and Jebel Ali, Salala and Chahbahar ports are the examples of this planning. The land procurement policy and physical infrastructure to built railway track and intermodal transport is also within the proposed plans at the Gwadar port area. This area is prepared to do following activities which include, warehousing, holder cargo station, re-bundling, handling plants, light assembling, and collecting products. Furthermore, the area of free economic zone at Gwadar port provide exemption from any kind of duties and taxes and therefore saves huge money of investors in this area. Build Operate Transfer (BOT) trade strategy applies for the development and operation purposes at Gwadar port (Ministry of Ports and Shipping, Gwadar Port Authority, 2015). The significant features of free zone region are 
- There are no import export duties are applicable

- There are no customs duties are enforced

- There is no tax imposed for any kind of machinery, equipments and goods imports from china for the purpose of constructing port and relevant projects

- Owner of the project like market players provided basic regulations

- All projects and progress will be according to Built Operate Transfer (BOT) scheme

- Organized and managed by qualified personnel

- There are no taxes or duties imposed for facilitation in cargo space for goods

- The production sector which facilitates in growth of small and medium industries is provided with low business cost

- Sharing with domestic economy as basic component of production development

- Supporting for port efficiency

- Importantly income tax for corporations is waived off for a period of 23 years

- Further income tax for corporations is minimised for a period of ten years after 23 years of tax exemption by $50 \%$. This is a proposal yet.

- Import and exports of all kinds of processed and ended goods are totally exempted from custom duties

- Mechanical equipments, raw substance for production and heavy machinery are free from any kind of duties

- Complete repatriation of income

- Complete repatriation of investment

Foreign investors are eligible for complete ownership rights

- Broader exemptions are

- There is no income tax for corporations up to 23 years time period

- Income from interest on loans is exempted from tax levied

- Stamp duties are exempted for the purpose of getting loan

- Any kind of federal and provincial taxes exempted in this area for a period of 23 years

- More importantly, there are no custom duties and further taxes imposed on substance, machinery, equipments and tools which bring in to country for the purpose of building structure, extension or construction work of port for the period of 40 years

- All custom duties on ship bunkers oils are exempted

CPEC logistics investment in Pakistan and alongside the corridor in the region comprises on highway projects to provide a comprehensive network. Following is the detail of such highway networks. 
- Main road between Khuzdar and Basim known as N-30

- Dera Ismail Khan to Quetta city N-50 main highway

- Havelian city Dry Port on the main route

- Maintenance and upgrading of Karakoram HighwayII from Havelian to Thakot (Completed)

- Maintenance and upgrading main line 1 known as ML-1

- Maintenance and upgrading of Karakoram Highway III from Raikot to Thakot (Completed)

- Connecting Optical Fiber cable between Rawalpindi and Khunjrab (Completed)

- Connecting Karachi to Lahore through construction of Sukkur and Multan motorway (Completed)

Transport and Overland Logistics Initiatives and Arrangements for CPEC by Pakistan

In this part of article, the authors endeavor to draw a reasonable picture of Pakistan transport and logistics area, the flow issues which the government is facing and furthermore the activities taken by the administration to set up logistics infrastructure for upcoming CPEC investment in the country. Iqbal, (2017) informs that transport and logistics sector in Pakistan comprises railway tracks, roads, ports, and shipping and aviation sub-sectors. Roads and roads transport drives the blend and hold 93 percent of passengers and 94 percent of the cargo movement. In this regard, the Pakistan Railways has lost in its competition with road transport, and now hold just six percent of the cargo movement due to lower charges offered by the latter and its greater efficiency. Due to such railway situation, the vehicles burden is shifted to the roads and consequently raises the transportation expense including imported fuel charges. The weak cargo handling and subsidy on passengers movement by the government, has adversely affected financial strength of the railroads. Therefore, railway sector is constantly confronting problems (World Bank Report, 2012).

In a broader perspective, Karachi as well as Bin Qasim ports handle the greatest piece of imports and exports (95\%) and these are situated at southern parts of the country. However, in current situation where Gwadar port is not fully functional, most of the trade is conducted through Karachi port. Additionally, owing to insufficiently advanced framework of such ports, they are inadequate in ability to control the busiest port activity. While the ship overseeing charges have decreased as of recently, yet at the same time there is a prerequisite for an efficient framework. It is appropriate to say here, that the nation has an across the board waterway framework, which was predominantly found on five rivers, yet lamentably inland water transport is relatively missing. A decided arrangement will be made at some phase in the plan time frame to take advantage of the potential outcomes of inland 
water systems relating to logistics and transportation along with coordinations (Pakistan Economic Survey, 2014-15).

Ernesto, (2006) states that logistics and transportation expense become cost effective with coordinations among administrations and global competition policy, however in opposite, Pakistan lags behind to offer such economical effects relatively as compare with regional and global trade partners owing to different insufficiencies. In this manner, such reasons the expanded transport costs may disrupt the exports sector of the nation, and thus it may badly affects investment for the export based organizations. In addition, due to the fact that the private sector commitment is insufficient and limited to some sub sectors particularly, therefore the extra burden is shifted towards public bodies. In the Public Sector Development Program (PSDP), there are a ton of applications with specific conveyances, causing delays and backs off the pace of execution.

Subhan, (2013) states that the transport and logistics department is considered most important aspect for the progress of the economy as well as small industry of the country. Logistics sector comprises on different activities such as, warehouses, cold storages, packaging services, transportation and physical infrastructure and distribution of goods to the clients at their destinations. Furthermore, logistics is also very important and has a key role to play in SME agriculture as well as industrial SMEs sectors apart from transportation sector. Supply chain management is another significant part of logistics which involves different vehicles and services like trucks, lories, goods clearing agents and freight matters. In this regard, there is deficiency of prescribed rules and regulations for logistics area in many parts of the world and it creates many operational as well as market based issues and consequently drops the progress rate of SMEs sector (Chugtai, 2014). Pakistan is also one of these countries where logistics services are being dealt without any proper freight regulatory system and it can further disturb the logistics investment by the Chinese or domestic investors under CPEC projects particularly in logistics SME sector. This part of research provide an analysis of logistics rules and regulatory system around the world and comparison with current Pakistani system to draw the deficiencies in order to get better results from logistics investments.

\section{Legal and Regulatory Issues in Pakistan Logistics and Freight Forwarders Sector}

Pakistan freight forwarders business faces many regulatory issues with inefficient management involved in transport and logistics department which consequently provide poor economic performance in the country. Watanuki, (2015) states that in East Asian countries and Greece where number of departments and bodies supervising freight forwarders business but with weak administration and therefore none of these become efficient. Furthermore, in Pakistan freight forwarders business is affected adversely by number of reasons and include, non confirmation of logistics rules and regulations, and due to this factor many untrained and non 
skilled person enter in to the logistics sector which consequently slows down the progress of the business.

Moreover, Pakistan has faced issues to identify the causes of slow development of freight business and how to solve to improve logistics sector on advance basis. The lack of information and knowledge over logistics issues, it is difficult to draw better regulatory policies. In this regard, this part of research intends to provide the criteria for regulatory system of logistics and the improvements it require for better competition in Pakistan particularly.

For this purpose, this part also put forward situations to be dealt for better regulations in Pakistan by analyzing current logistics policies in particular freight forwarders sector. This part of research further evaluates a "freight forwarders regulatory framework" and distinguishes sector shortcomings that need work. The basic purpose is to inquire state recognition of the freight forwarder business with an institutional plan a usage course of action with an authorization system and with clear division of obligation among partners and how they can adopt flexible rules and regulations.

Pakistan logistics sector regulations are influenced by number of issues. Such issues adversely affect the administrative efficiency in the department. At a broader level, these issues include absence of relevant legislation, involvement of different governing bodies, political preferences, rigid and old practices, and various social elements. In presence of these issues, Pakistan logistics sector is likely to be not ready to embrace CPEC investments until a strong and upgraded logistics regulatory system is introduced in the country which of course necessitates relevant Parliamentary legislation (Recorder Report, 2018).

Logistics regulations in Pakistan are not covered by any single legal document and therefore given under multiple institutes which cause overlapping and fragmentation of the policies. In this way, logistics transport business entities are required to face many regulatory bodies. For example, to start trucking business in Pakistan, the permission is required from the Ministry of Communication as well as from Customs department for establishing ware house facility in connection to trucking business. In order to seek permission from customs department for warehouse, the fire regulator agency is involved and also need permission from this body. In setting up logistics business in Pakistan, the foreign investors are more likely to face problems and rigorous procedures in this activity. Such procedures are laid down by the foreign direct investment laws under the policy guidelines of board of investment and mainly supervised by the Ministry of Trade. In Pakistan, the foreign investors for logistics business also need to adhere the other operational regulations managed and supervised by other ministries like environmental department to check the investment consequences, interior ministry to check vehicles, security and cargo transported from various check posts and finance ministry to fix charges and taxes in this regard. To start and run logistics business, investors ought to know and follow all these procedures. In this regard the foremost 
problem is to locate the relevant information at single place in presence of different ministries and regulatory departments and this causes non simplicity of procedures. There is no "one stop centre" in Pakistan system, for instance, a logistics ministry, to provide and manage all logistics business related requirements and relevant procedures as well as regulations. Moreover, the relevant logistics mechanism has been run and managed through different ways (World Bank Report, 2013). In this regard, under CPEC logistics investment, various Chinese and domestic companies and businessmen plan to start business are highly expected to face such issues in Pakistan. The proper planning and advancement in this regard is yet to be seen by the Pakistani authorities.

Furthermore, such disintegration gives logistics administrators a high obstacle to provide immediate benefits within their organization and due to this problem logistics operators need to hire services from external people. In addition, setting up a logistics services business under CPEC may need joint ventures. In the event that foreign organizations mean to give better logistics services, they need to enter into agreements with domestic companies in shape of partnerships or joint business ventures and consequently it disturb their establishment of logistics services activity in Pakistan. Besides, institutional disintegration among prominent ministries and bodies give weak compliance of regulations and certain laws.

Apart from disintegration problem, local regulations and both bilateral and international transport conventions and agreements have significant role to play in this regard. Developing states specifically are enthusiastic to make better arrangements of transport administrations since the tax generation and income through cross border trade is enhanced and subsequently raises domestic revenues. Along these lines, policy providers have many alternatives to utilize their political power after choosing transport conventions and treaties. Moreover, vast political majority in governments may influence arrangement requirements in a few nations. After many turnovers, regulations may turn out to be non consistent and inefficient. Also, financial experts assess benefits interests through foreign direct investment strategy.

For such reason, some arrangements are made where such experts endeavor to shield certain areas from foreign investors. In a situation where logistics service providers enter in to foreign country for business. It can enhance the financial position of the state, however due to this policy; the local logistics service provider companies may have adverse affects on their business and income. With an endeavor by the state to protect domestic businessmen, the foreign investors may face various obstacles through strict regulatory framework. It may happen in CPEC projects where high income Chinese logistics companies enter into Pakistan and the already existing domestic companies in the country adversely affected due to modern technology and better facilities bringing by such companies.

The law making policies which likewise influence logistics regulations are frequently influenced by practices and domestic structure within a state. In the 
meantime, even among such states which were remained under colonial system, current institutional quality extraordinarily differs on account of domestic culture and social standards. There is an association within capacity of achievement through exchange as well as present differences in previous territories. In such situation, Britain ruled over Pakistan, Singapore and South African, however, utilizing a subsequent amassed indicator to quantify the nature of the instructional system, its scores differed, 1.57, 0.41 , and - 1.09, individually. This difference prevails due to the distinct economical circumstances of these states. For this reason, it can be said that higher logistics arrangements also indicate the better economical situation of the country as Singapore is ahead from South Africa and Pakistan. Along these lines, nations with comparative pioneer impact infrequently have the equivalent regulatory system in their statutory laws.

This happens in Pakistan where, freight forwarders businesses are not recognized by law and therefore face many obstacles to get the relevant facilities from public sector. The current freight forwarders recognition under Pakistan law and the preparations of this sector under CPEC logistics investment is highlighted by Shakeel Ahmad Chairman "Pakistan International Freight Forwarders Association" during an interview to the Business Recorder organization (Shakeel, 2018). He states that "To date, Pakistan has not introduced a transport or logistics policy, though one has been in the works for several years and we hear that it will be approved soon. With CPEC taking off, transport and logistics policy is on an urgent need indeed, in Feb, the National Assembly passed a bill titled 'Pakistan Courier and Logistics Regulatory Authority Bill 2018 (PCLRA) to regulate the industry and establish Pakistan Courier and Logistics Authority. However, out of a total of 11 members, nine are government officials whereas only two belong to the private sector, Pakistan Post Office (PPO) enjoys a permanent seat on the board of Pakistan Courier and Logistics Authority "PCLA", a host of stakeholders from logistics, freight forwarding, and courier companies, shipping and cargo agents, CSF terminal and port operators should have been consulted and involved in drafting of the legislation. To capture business opportunities, smaller logistic companies and contractors will require financing as the existing fleet cannot be used and will have to be upgraded to adhere to Euro standards".

In light of these concerns and worries by the Chairman of Pakistan International Freight Forwarders association, policy regarding CPEC logistics investment must be drawn by the authorities immediately.

These factors include legal recognition of freight forwarders business, advance physical infrastructure, exclusive transport and logistics ministry, private investors involved in freight forwarders business and supportive environment for foreign investment including concerned laws and regulations. 


\section{Conclusion}

This study concludes that the economic progress in Pakistan for a longer run and better results from CPEC overland logistics investment arrangements can only be possible with upgraded and cost effective logistics as well as transportation management system. Efficient transport sector not only improve domestic performance but also increase export capability of the country. Pakistan transport and logistics sector shows progressive attitude even though the economic situation of the country remains weak. Furthermore, due to current investment and industrial growth, the GDP rate of the country seems to be better and economic betterment can be seen. The economic situation of Pakistan getting better in recent time and it further predicts the high level load and increase within country traffic on roads and railway tracks in both passengers and cargo sectors. In current scenario, road and rail tracks of Pakistan is struggling with 433 billion passengers per kilometer as well as 269 billion tones per Kilometer. This situation further become more complicated where 614 billion passenger as well as 381billion tones respectively will be added by 2020 due to the CPEC investment opportunities which involve heavy movement of cargo and passengers. In the same vein, the transport and logistics sector of Pakistan presently catered three million people employment which further expected to reach 3.8 million jobs at the time of first phase of CPEC (Ministry of Planning, Development and Reform, 2017).

For better economic situation, legislature knows about the imperative part of the area in the general economic advancement and in enhancing the intensity in exports. It is, in this way, dedicated to actualize a far reaching advancement activity for modernizing the segment through a persistent procedure of change with the help of sustainable planning of changes to secure the further investments in different sectors. The scheme of public sector development program further provides $30 \%$ shares annually to this sector; however this contribution is still not enough to meet the current as well as future demands. For a better planning, at least three to four times extra amount put into this sector to cater all time high demands established by economic progress in the country. To achieve these targets, public private investment can be useful as high amount investment is expected through this policy (Idrees et al, 2019). 


\section{References}

Alam, I. (2014, August, 26). Rules being bypassed to facilitate China investment', The Nation.

Balisacan. Arsenio M. Pernia \& Ernesto M. (2002). Revisiting Growth and Poverty Reduction in Indonesia: What do Sub national Data Show, ERD Working Paper No. 25, Asian Development Bank, Manila.

Bowersox. D.J, \& Closs. D.J (2000).'Ten-mega trends that will revolutionize supply chain logistics' Journal of Business Logistics, 21 (2) , pp 1-15.

China Pakistan economic corridor council, JJC OF CPEC $3^{\text {rd }}$ meeting held in Beijing http://www.c-pecc.com/enindex_en.html

Chugtai, M. W. \& Alam. I, (2014). 'Small and Medium Enterprises as Engine in Economic Growth of Pakistan: An Empirical Analysis' Research Journal of Economic and Business Studies. 3 (10) pp 45-51.

Council of Supply Chain Management Professionals (CSCMP) https://cscmp.org/research/organizing-supply

Ernesto, Sanchez-Triana \& Santiago, E. (2006). Transport Competitiveness in Pakistan: Analytical Underpinnings for the National Trade Corridor Improvement Program, Innovative Development Strategies (IDS), World Bank report Report No. 36523- PK.

Fan. S, L. \& X. Zhang (2002). Growth, Inequality, and Poverty in Rural China: The Role of Public Investments, Research Report 125, International Food Policy Research Institute, Washington D.C.

Glewwe, P. Gragnolati, M. \& Zaman, H. (2002). Who Gained from Vietnam's Boom in the 1990s? An Analysis of Poverty and Inequality Trends World Bank Working Paper 2275, Washington D.C.

Government of Pakistan, Ministry of Planning, Development and Reform. (2017), Long Term Plan for China Pakistan Economic Corridor (2017-2030). Islamabad: Government of Pakistan, Ministry of Planning, Development and Reform.

Idrees, (2019). The Role of Logistics Infrastructure in China Pakistan Economic Corridor Energy Generation Development, International Journal of Energy Economics and Policy, Vol. 9 No. 1, pp. 262-268.

Idrees, R.Q., Shapiee,R.,Ahamat,H.\& Hanwei,L.(2018). How Logistics Investment Arrangement is a Key Concern to China Pakistan Economic Corridor(CPEC)? A Legal and Policy Analysis of CPEC Logistics Investment Model and Future 
Challenges for Pakistan, International Journal of Asian Social Science, Vol.8 No. 11, pp.1059-1067.7.

Iqbal. W, SEZs China Seeks Extra Incentives https://fp.brecorder.com/2017/07/20170714197621

Klaus. Schwab, The Global Competitiveness Report 2013-2014, World Economic Forum. https://www.weforum.org/reports/global-competitiveness-report2013-2014

M.Sreenivas, T. Srinivas, The Role of Transportation in Logistics Chain [2011] https://www.siam.org/journals/ plagiary/1814.pdf

McGinnis. M.A. (1994). 'Military Logistics: Insights for Business Logistics' International Journal of Physical Distribution \& Logistics Management, 22 (2), p 22.

Mentzer. J.T, \& Flint. D.J (2001). 'Logistics service quality as a segment-customized process' Journal of Marketing 65 (4), pp 82-104.

Ministry of Ports and Shipping, Gwadar port authority, "Gwadar port and CPEC: A presentation to the Parliamentary committee on CPEC" [2015].

Ministry of Foreign Affairs, Government of Pakistan Joint Statement Deepening Comprehensive Strategic Cooperation between the People's Republic of China and the Islamic Republic of Pakistan

[2015] http:/ / www.mofa.gov.pk/prdetails. php?prID=1200

Pakistan Economic Survey, 2014-15.

Recorder Report. (2018). 'Logistics industry lacks clarity over CPEC' An interview with Chairman Pakistan International Freight Forwarders Association. Available at https://fp.brecorder.com/2018/06/20180608378988/

Recorder Report. (2018). International Freight Forwarders Association. https://fp.brecorder.com

Shan. L, Zhang. Z et al, Integration of logistics resources based on logistics network. Contemporary Logistics http:/ / search.proquest.com/docview/1355496723?accountid=27294

Shapiee, R., and Idrees, R. Q. (2017). China Pakistan Economic Corridor (CPEC); Most Valuable Dream for Pakistan through Economic Integration in the Region but May Not Become True without Up gradation of Physical Infrastructure and Legal System, Beijing Law Review, Vol.8 pp. 481- 498.

Strategic Environmental, Poverty and Social Assessment of Trade and Transport Sector Reforms, Report No 71812-PK, World Bank, 2012. 
Subhan. Q. A, Mehmood. M. R, Sattar. A, (2013). 'Innovation in Small and Medium Enterprises (SME's) and its impact on Economic Development in Pakistan' International Business and Social Science Review, pp 3-4.

Watanuki. Maika, (2015). Review of Logistics Service Regulations for Freight Forwarding Business: What should be Addressed for a Better Logistics Regulatory Framework. Policy Research Working Paper No. 7401. World Bank Group. Trade and Competitiveness Global Practice Group.

World Bank Report (2013). Unlocking Growth Potential through Regulatory Reform and Complementary Measures, Pakistan Perspective, 82569, Washington DC.

Zhai. F,(2018). The Benefits of Regional Infrastructure Investment in Asia: A Quantitative Exploration - ADB Working Paper, No 223 http://www.adbi.org/workingpaper/2018/06/30/3923.regional.infrastructure.i nvestment.as ia/\#sth ash. PuyLmWmo.dpuf 